\title{
Application of microtremor HVSR method for preliminary assessment of seismic site effect in Ngipik landfill, Gresik
}

\author{
Siti Nurlita Fitri ${ }^{1, *}$, Ria Asih Aryani Soemitro ${ }^{2}$, Dwa Dewa Warnana ${ }^{3}$, and Nila Sutra ${ }^{1}$ \\ 1,4 Graduated student of Civil Engineering Department, Institut Teknologi Sepuluh Nopember (ITS), \\ Surabaya, Indonesia \\ ${ }^{2}$ Civil Engineering Department, Institut Teknologi Sepuluh Nopember (ITS), Surabaya, Indonesia \\ ${ }^{3}$ Geophysical Department, Institut Teknologi Sepuluh Nopember (ITS), Surabaya, Indonesia
}

\begin{abstract}
This paper presents an investigation based on affected areas of earthquakes based on the micro-tremor horizontal-to-vertical ratio (HVSR) method around the Ngipik Landfill, Gresik. Ngipik landfill applies an Open dumping system with no protective layer to prevent groundwater pollution. Hence, the effect of the earthquake was investigated for preliminary assessment of leachate's leakage. The micro-tremor measurements were performed by dividing the area into a grid with a $25 \mathrm{~m}$ distance. The predominant frequency $\left(\mathrm{f}_{0}\right)$ ranges between 1.1 and $3.65 \mathrm{~Hz}$ and the peak of HVSR (Am) varies from 2.04 to 7.16. The vulnerability index $(\mathrm{kg})$ displayed the level of soil damage due to ground motions; the highest $\mathrm{kg}$ values signified the weaker zones during earthquakes and also indicated the leachate spread. The result of this paper might consider to seismic stability analysis of leachate recirculation landfill.
\end{abstract}

\section{Introduction}

Gresik is one of several districts East Java that has active faults and several seismic activities. The after effect on the soil surface directly causes deformation and soil vibrations, leaving this region vulnerable to seismic activity which damages local infrastructure.

The geological feature of Gresik consists of alluvial sedimentary, basin, limestone grumusol, red mediteran and sandstone with sediments in form of limestone and clay. Areas with geological features such as alluvial sediment, tuff and sandstone pose a greater potential danger to the effects. It bolsters soil vibration intensity caused by the amplification and interaction of ground vibrations to buildings due to earthquakes [1].

Ngipik Landfill is located in Gresik and has been functional since 2002. The land mass of Ngipik Landfill is 6 hectares large but the disposal zone area is about 4 hectares, and the height of the landfill is about $10-12 \mathrm{~m}$. Currently, it is still in use as an open dumping method for disposing the waste. This method does have a protection layer to prevent groundwater pollution from leachate.

\footnotetext{
*Corresponding author: nurlitafitri@gmail.com
} 
Leachate is a liquid that passes through refuse which has been extracted and suspended from the waste reaction. Leachate develops from moisture that is as a result of decomposition. The chemical composition of Leachate includes $\mathrm{Ca}, \mathrm{CaCO} 3, \mathrm{Mg}, \mathrm{K}, \mathrm{Na}$, $\mathrm{Fe}, \mathrm{Si}, \mathrm{Al}, \mathrm{Cl}, \mathrm{SO} 4$ and ammoniac which contaminates ground water [2].

The local site effect is the combined effect between the geological site condition and topography of the site. Local site effect fosters earthquake amplification. Accumulations of waste with irregularity of Leachate circulation in the geological site of Ngipik Landfill should be checked to prevent the spread of Leachate.

Actually, although the theory of local site effects has been enveloped, the geology subsurface's assessment with geophysical surveying as though borehole method is limited to post-factum (post-failure) and expensive to local scale study. After that, the microtremor assessment is considered due to its cost efficiency and speed which surpasses the other method. [3]

This report is aimed at assessing the local site effects of landfill in Ngipik Landfill, Gresik - East Java Indonesia. The local site effects are characterized by high levels of seismicity (Figure 1). Based on Map of Seismic hazard in Indonesia, East java has a ground acceleration value for a rock site about $0.2 \mathrm{~g}$ to $0.3 \mathrm{~g}$ for 100 -year return of a design criteria. [4].

The microtremor measurements analysis (HVSR Method) has been specified from the Nakamura technique to determine the predominant frequency (f0), amplification factor $(\mathrm{Am})$, vulnerability index $(\mathrm{Kg})$. The parameters were combined to determine the relationship between the local site effects. [5],[6],[7].

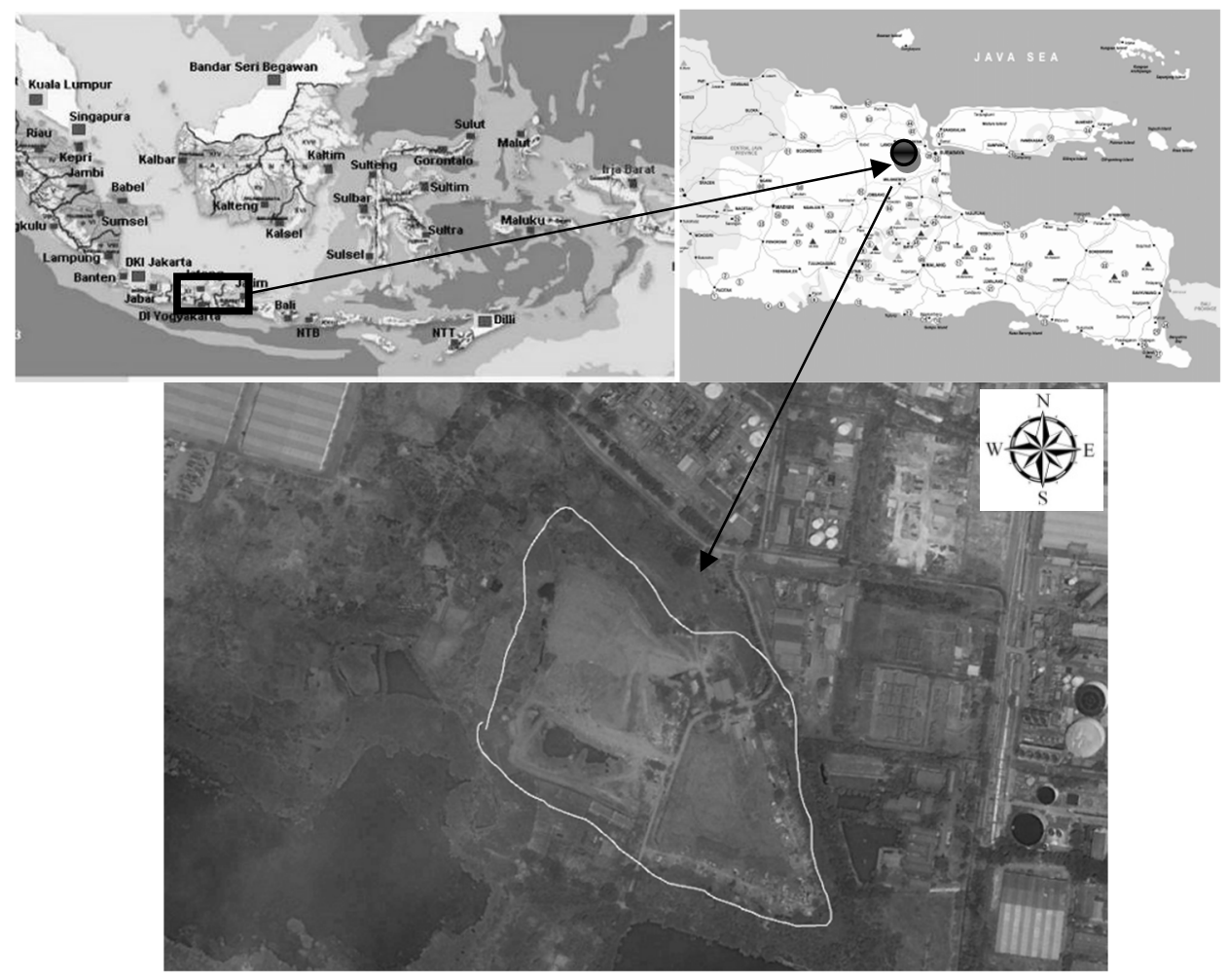

Fig. 1. Location map of study area. 


\section{Material and methods}

\subsection{Geotechnical investigation}

The soil characteristic was taken from 3 boreholes on field which were predominantly dominated by clay with N-SPT value varied from 2 to 5 blows on the surface soil until 5meter depth. The result is classified as soft clay down until 5 meters depth, and the next depth varied from medium to stiff clay in the 10 to 30 meters depth mark. [8].

\subsection{Microtremor measuring and data processing}

The microtremor investigation was conducted on August 2017, on 25 x 25 m grid around of the main area. The location of geotechnical and microtremor investigation is shown below on Figure 2.

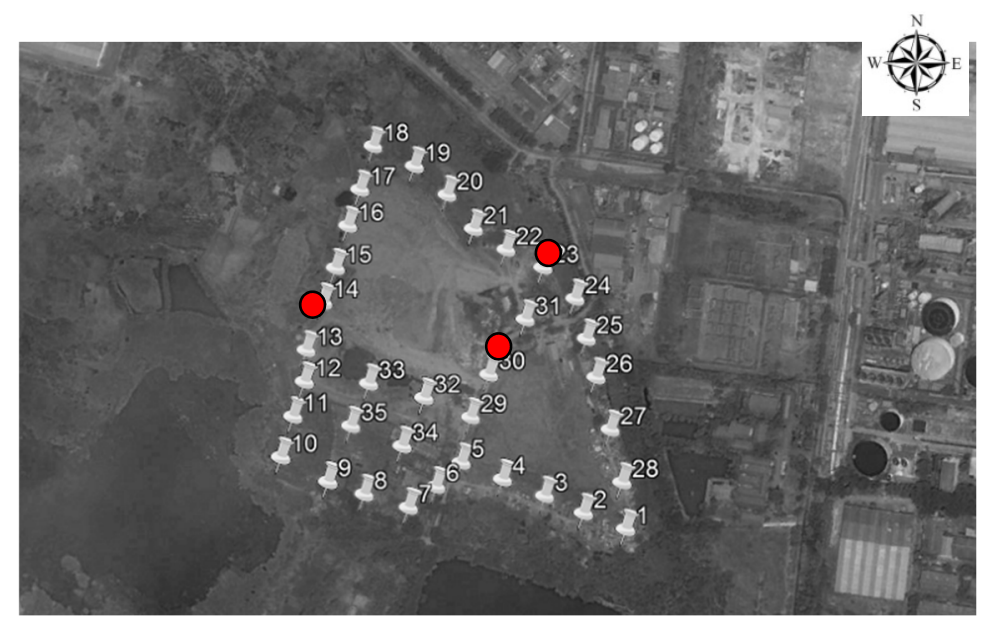

Fig. 2. The location of microtremor investigation (white sign). Geotechnical investigation (red dots).

The microtremor measurement was measured for 30 minutes \& ambient noise was recorded during this period. To achieve HVSR at each test, the data is prepared following this procedure; filtered frequency about 0.2 and $25 \mathrm{~Hz}$ with 4 poles Butterworth filter and will be removed if it passed the mean and liner trend; time owned by each signal obtained 20 second length with cosine taper 5\%. The FFT data has processed and smoothed by the Konno and Ohmachi (1998) method with $(b=40)$ in each window. The window has a result of vertical and horizontal spectrum ratio. Lastly, the average and standard deviation of this spectrum was determined to get HVSR curve. Overall HVSR analysis is performed using Easy HVSR Software.

HVSR analysis from microtremor measurements has to satisfy the criteria defined by SESAME project (Table 1) for reliable measurements [9]. The criterion which has to be analyzed on HVSR has been determined by SESAME (Table 1) in order for the HVSR measurement's results to be reliable [10]. The H/V peak and H/V curve criteria has been determined for an increased reliability of the HVSR curve. 
Table 1. HVSR curve reliable criteria (Sesame, 2004).

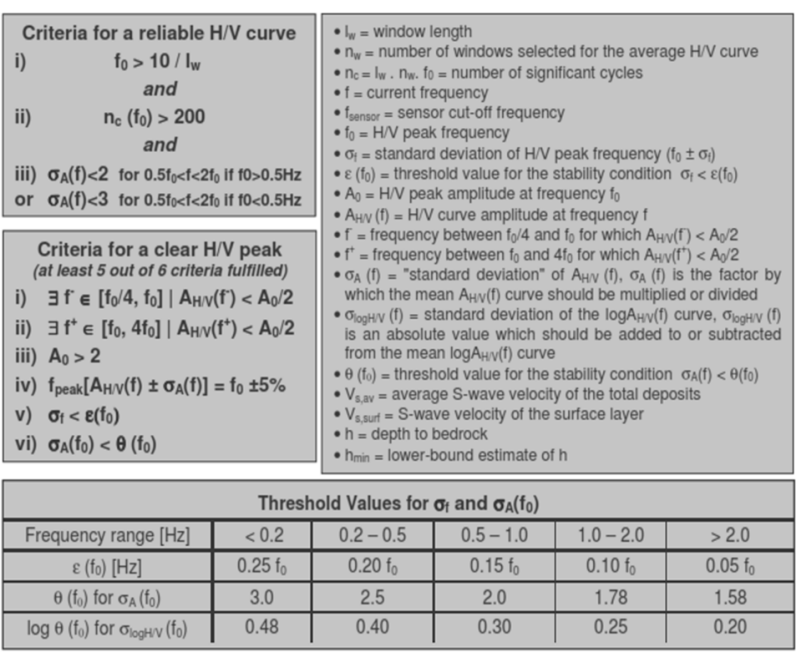

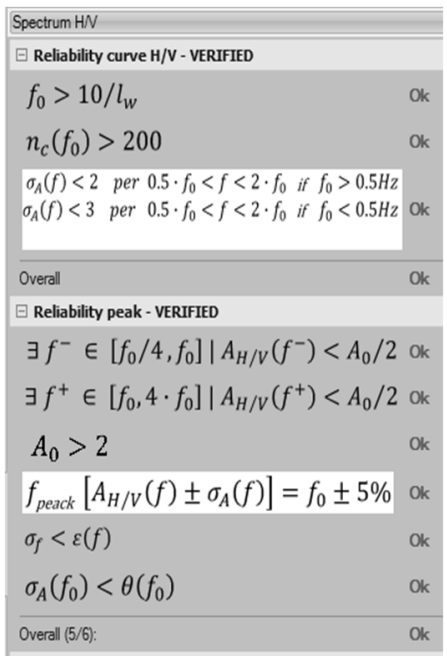

\section{Results and interpretation}

\subsection{Distribution of predominant frequency $\left(f_{0}\right)$ and amplification factor $\left(A_{m}\right)$}

Based on Figure $3 a$, the value $f_{0}$ where the allocation of predominant frequency is relatively uniform is about $1 \mathrm{~Hz}$ and $3.65 \mathrm{~Hz}$. The lowest value is found in the south and northwest of corners of the landfill location. The $f_{o}$ value represents the pattern of the topographic area. The thickness of soil (h) can be calculated as follows.

$$
\mathrm{F}_{0}=\mathrm{V} / 4 \mathrm{~h}
$$

Where $\mathrm{V}$ refer to velocity of shear wave. The greater depths of the bedrock can be represented with the smaller $\mathrm{f}_{\mathrm{o}}$.

Figure $3 \mathrm{~b}$ represents the peak ratio of HVSR spectrum or amplification factor sites which range between 2.04 to 7.16. The high value factor amplifications were found at the east and northwest area. The landfill's height in the northwest area is the highest, but factors that may affect the amplification factor are more than just the topographic effect factor [10].

There is no correlation of Amplification and natural frequency. The soil depth is not strongly controlled by variation of Am value. The effect of the saturation state of the bedrock is insignificant; the factor that has the greatest influence is the change of saturation condition of the soil layer. Hence, it can be concluded that the dominant control factor in the Am variation is the geological factors [11]. 


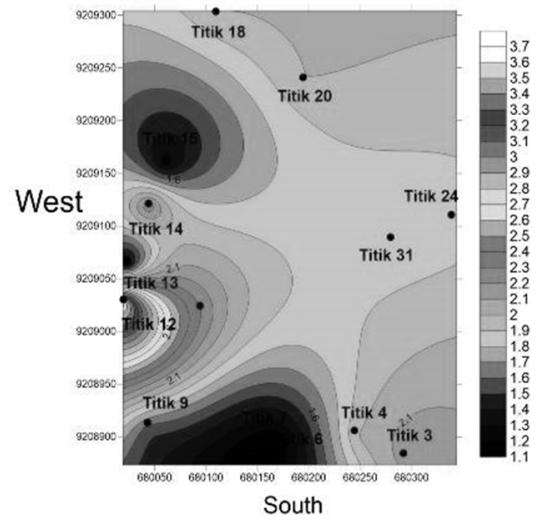

(a)

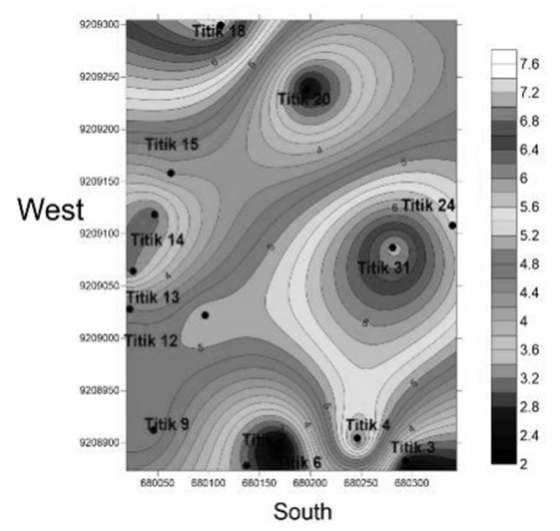

(b)

Fig. 3. (a) Distribution of soil natural frequency ( $\left.f_{0}\right)$. (b) Distribution of amplification factor $\left(A_{m}\right)$ on study area.

\subsection{Distribution of Soil Vulnerability Index (kg)}

The Vulnerability index combined the effect of amplification and natural frequency using the formula.

$$
\mathrm{Kg}=\mathrm{Am}^{2} / \mathrm{F}_{0}
$$

This method can be applied to identify areas prone to greater seismic hazards and damage. The high value represents an indicator which could be helpful in choosing the weak points of this area. During earthquake, the weak zones and indicated the Leachate spread due to ground motions of subsurface landfill.

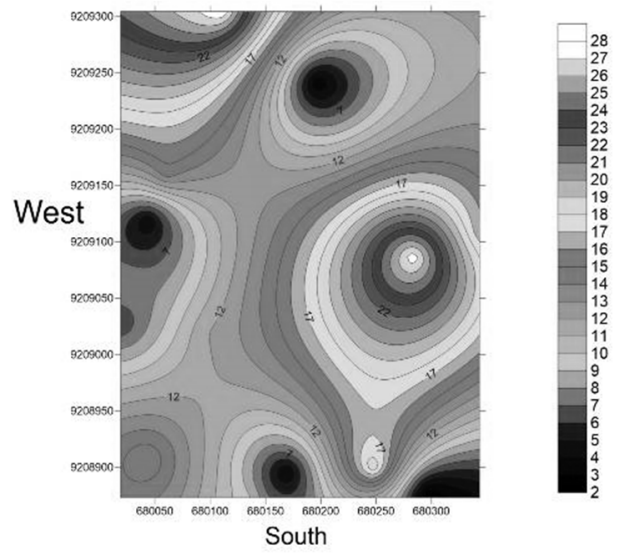

Fig. 4. Distribution of soil vulnerability index ( $\mathrm{kg})$.

\section{Conclusion}

Microtremor and geotechnical measurement are generally employed for preliminary assessing of site effect. Variation of soil subsurface properties and bedrock depth was provided to give initial information. Concurrently, the microtremor's preparation and 
measurement are kept low due to no other active source is required. Hence, the microtremor HVSR method is very helpful in determining preliminary seismic micro zonation in landfill.

The value of the predominant frequency $\left(f_{0}\right)$ is between $1.1 \mathrm{~Hz}$ and $3.65 \mathrm{~Hz}$ and peak of HVSR $\left(\mathrm{A}_{\mathrm{m}}\right)$ varies from 2.04 to 7.16 and effecting to Vulnerability index $(\mathrm{Kg})$. Large values of $\mathrm{Kg}$ were found at the Northwest areas; these zones are considered as weak zones and are indicated in the leachate spread. This result could be considered as a preliminary assessment of the local site effects due to the recirculation design of Leachate.

\section{References}

1. Nakamura, Y., Gurler, E.D., Saita, J., Rovelli, A., Donai. 12th WCEE in Auckland, NZ 2660/6/A (2000)

2. Agustina, Ummy Arofah., ITS Undergraduate Thesis of Environment Engineering (2013)

3. Warnana, D.D., Soemitro R.A.A., Utama, W. International Journal of Basic \& Applied Sciences IJBAS-IJENS, 11 (2011)

4. Irsyam M., Widyantoro S., Meilano. I., Natawidjaja D.H., Budiono B., Triyoso W., Hendriyawan, Peta sumber dan bahaya gempa Indonesia tahun 2017, ISBN 978-6025489-01-3 (2017)

5. Nakamura, Y., A, Quarterly Report of RTRI, Railway Technical Research Institute (RTRI), 1989, 30, No.1.

6. Nakamura, Y., Real Time Information Systems for Seismic Hazards Mitigation UrEDAS, HERAS, PIC, Quarterly Report of RTRI, 1996, 37, No. 3.

7. Nakamura, Y., World Congress on Railway Research in Florence, Italy, November, 1997.

8. Sutra N., Warnana, D.D., Soemitro R.A.A., Proceedings of Soft Soils (2016)

9. SESAME, Guidelines for the implementation of the $\mathrm{H} / \mathrm{V}$ spectral ratio technique on ambient vibrations: measurements, processing and interpretation., 62 (2004).

10. Warnana, D.D., Soemitro R.A.A., Utama, W. Journal of Basic and Applied Scientific Research. 1(5) 412-417 (2011)

11. Yang Jun, Journal Geotech and Geoenvironmental Engineering, 132, (2006) 